\title{
EFFECT OF OPERATING PARAMETERS AND FORMATION PROPERTIES ON PENETRATION RATE IN SOME SANDSTONE ROCKS USING DIAMOND CORE BIT
}

\author{
Mostafa M. Elbeblawi ${ }^{1}$, Mohamed A. Sayed, \\ Gamal Y. Boghdadi ${ }^{3}$ and Helal H. Hamd_All $h^{4}$ \\ 1, 2, 3: Stuff members in the Mining \& Metal. Eng. Dept., Faculty of \\ Engineering, Assiut University \\ 4: Demonstrator in the Mining \& petroleum Eng. Dept., Faculty of \\ Engineering, Al-azhar University, Quena
}

(Received November 21, 2011 Accepted December 19, 2011)

\begin{abstract}
In this study four sandstone rocks were drilled by diamond core bit using a fixed laboratory-drilling machine at 400 and $1200 \mathrm{rpm}$, rotary speed, over a range of weights on bit (WOB) $12,18,24,30, \ldots \ldots ., 150 \mathrm{~kg}$. Operating parameters of the drill bit such as WOB, penetration rates $(P R)$, torque $(T)$ and specific energy (SE) were continuously monitored during the drilling trials. Besides the effects of formation properties on the penetration rate were monitored. Relationships between $W O B$ and both PR, torque $T$ and $S E$ were determined and the relationship between $P R$ and $S E$ was given. Graphs are presented and can be used to predict diamond-drilling performance easy and fast.
\end{abstract}

KEYWORDS: Penetration rate, rotary speed, Weight on bit, Specific energy,

\section{INTRODUCTION}

In the rotary drilling method, the hole is drilled by a rotating bit to which a downward force is applied. Rotary drilling drills have been extensively used in many applications in our live such as water, oil, and gas well drilling and were also used in open pit mines for overburden removal. [1]

In the rotary drilling penetration rate $(\mathrm{PR})$ is a very important variable due to its effects on the time and cost.

The penetration rate is very necessary for cost estimation and planning of the drilling project. Drillability and penetration rate can be defined as similar terms. Drillability indicates whether penetration is easy or difficult, while penetration rate indicates whether it is fast or slow $[2,3]$.

Penetration rate value is controlled by two main factors namely operating parameter and formation properties. Operational variables (operating parameters) are known as controllable parameters. Rock properties and geological conditions are uncontrollable parameters [3, 4].

The main operating parameters such as rotational speed, thrust, and flushing are the three main elements on which the driller can intervene within the limits of possibilities of the equipment. Formation properties are characteristics that effect drilling performance and are the unalterable factors $[5,6]$. 
Drilling velocity is dependent on a lot of geological parameters: Those principal parameters include jointing of rock mass, orientation of schistosity (rock anisotropy) degree of interlocking of microstructures, porosity and quality of cementation in clastic rock, degree of hydrothermal decomposition and weathering of a rock mass. [7, 8]

The specific energy (SE) is the main index related with all drilling parameters, and can be defined as the energy necessary to drill a determined volume of rock $\left(\mathrm{GJ} / \mathrm{m}^{3}\right)$. [5]

Rotary drilling rates of advance based on specific energy involves all types of energy consumed, such as energy of plastic deformation, friction, kinetic energy of chips, heat losses and energy of comminution. [9]

All drilling trials were carried out at two main rotary speeds, low speed (400 rpm) and high speed (1200 rpm).

Lengths of core produced from the testes are measured and time taken for the drilling is monitored so the penetration rate calculated is equal length of core per unit time. Note, the average penetration rates were estimated from the drilling trials at low and high speed for one and the same load.

The aim of this work is to study the effect of both operating parameters such as rotational speed, thrust and formation properties on the penetration rate in some sandstone rocks using diamond core bit.

\section{PROPERTIES OF THE TESTED ROCKS:}

Physical and mechanical properties such as density, porosity compressive strength, tensile strength and coefficient of friction are determined. Table (1) contains the average value for each property tested together with its standard deviation.

Table (1) Physical and mechanical properties of the tested rocks

\begin{tabular}{|l|c|c|c|c|c|}
\hline Rock type & $\begin{array}{c}\text { Density } \\
\text { gr/cm3 }\end{array}$ & $\begin{array}{c}\text { Porosity } \\
\mathbf{\%}\end{array}$ & $\begin{array}{c}\text { Compressive } \\
\text { strength, } \\
\text { MPa }\end{array}$ & $\begin{array}{c}\text { Tensile } \\
\text { strength, } \\
\text { MPa }\end{array}$ & $\begin{array}{c}\text { Coeffi.Of } \\
\text { friction }\end{array}$ \\
\hline Sandstone A & $2.02 \pm 0.009$ & $23.84 \pm 0.695$ & $110.96 \pm 9.33$ & $24.99 \pm 1.79$ & 0.70 \\
\hline Sandstone B & $1.97 \pm 0.006$ & $23.74 \pm 0.380$ & $127.11 \pm 6.49$ & $35.97 \pm 4.76$ & 0.59 \\
\hline Sandstone C & $2.034 \pm 0.007$ & $18.85 \pm 0.180$ & $142.70 \pm 6.85$ & $35.97 \pm 1.29$ & 0.66 \\
\hline Sandston D & $2.003 \pm 0.016$ & $21.38 \pm 0.707$ & $139.92 \pm 5.84$ & $25.18 \pm 1.99$ & 0.83 \\
\hline
\end{tabular}

\section{Experimental work:}

In the current research four types of the sandstone rocks were tested having various properties from different places in Aswan, Egypt were tested. Rocks prepared as blocks $20 \mathrm{~cm} \times 15 \mathrm{~cm} \times 15 \mathrm{~cm}$. Blocks tested in the laboratory by diamond bit with inside diameter $38 \mathrm{~mm}$ and outer diameter $40 \mathrm{~mm}$.

All drilling trails were carried out at low speed equals $400 \mathrm{rpm}$ and high speed equals $1200 \mathrm{rpm}$. Rotary speed in the tests measured by laser speedometer to monitors the applied speed. Water used as a drilling fluid for cooling the bit and remove the cutting. 
The weight on bit is applied using loads which are suspended by a movable wheel by wire rope. The wheel is fixed into the machine gear axis. Hence the load is transferred into the bit. This transfer load is checked and measured using proving ring. Load on the drilling operations drilling tests have been conducted using drilling experiments and rock under tests were recorded.

Applied load, actual speed, length of borehole (length of core) and time of drilling are recorded as results of drilling in sandstone (D) as an example, and the average values of penetration rates are shown in table (2)

Table (2) Experimental data of S.S. (D) at 400 RPM

\begin{tabular}{|c|c|c|c|c|c|c|c|c|}
\hline \multirow[b]{2}{*}{$\begin{array}{c}\text { WOB, } \\
\text { Kg }\end{array}$} & \multicolumn{3}{|c|}{ Length of core ,cm } & \multicolumn{3}{|c|}{ Time, min. } & \multirow{2}{*}{$\begin{array}{c}\text { Averag } \\
\text { e PR } \\
\text { cm/min } \\
\end{array}$} & \multirow{2}{*}{$\begin{array}{c}\text { Averag } \\
\text { e PR } \\
\mathrm{mm} / \mathrm{sec}\end{array}$} \\
\hline & Core 1 & Core 2 & $\begin{array}{c}\text { Core } \\
\mathbf{3}\end{array}$ & $\begin{array}{l}\text { Time } \\
1, \mathrm{~min} .\end{array}$ & $\begin{array}{c}\text { Time } \\
2, \text { min. }\end{array}$ & $\begin{array}{l}\text { Time } \\
\mathbf{3}, \mathbf{m i n} .\end{array}$ & & \\
\hline 18 & 14.5 & 14 & 13 & 2.2 & 2.3 & 1.9 & 6.58 & 1.1 \\
\hline 24 & 9.5 & 11.5 & 12 & 1.35 & 1.73 & 1.85 & 6.63 & 1.11 \\
\hline 30 & 11 & 12 & 13 & 1.55 & 1.70 & 1.8 & 7.11 & 1.19 \\
\hline 36 & 12 & 12 & 14 & 1.48 & 1.64 & 1.6 & 8.34 & 1.39 \\
\hline 45 & 14 & 12 & 8 & 1.21 & 0.62 & 0.51 & 15.48 & 2.58 \\
\hline 60 & 7 & 9 & 5 & 0.73 & 0.38 & 0.25 & 21.74 & 3.58 \\
\hline 75 & 13 & 13 & 10 & 0.73 & 0.75 & 0.53 & 17.94 & 2.99 \\
\hline 90 & 13 & 13 & 10 & 0.71 & 0.65 & 0.45 & 20.38 & 3.4 \\
\hline 105 & 14 & 14 & 11 & 0.73 & 0.50 & 0.51 & 20.04 & 3.34 \\
\hline 120 & 14 & 14 & 10 & 0.67 & 0.50 & 0.43 & 22.0 & 3.67 \\
\hline
\end{tabular}

\section{RESULTS AND DISCUSSION:-}

The following discussions show the relations between (WOB via PR), (WOB via Torque), (WOB via SE) and (PR via SE) at low and high speeds.

Table (3) shows PR, SE at 400 \& 1200 RPM for different WOB in tested rocks.

Table (3) Data obtained of PR and SE at low and high speeds for different WOB

\begin{tabular}{|c|c|c|c|c|c|c|c|c|c|c|c|c|c|c|c|c|}
\hline \multirow{3}{*}{$\begin{array}{c}\text { WOB, } \\
\text { Kg }\end{array}$} & \multicolumn{4}{|c|}{ Rock A } & \multicolumn{4}{|c|}{ Rock B } & \multicolumn{4}{|c|}{ Rock C } & \multicolumn{4}{|c|}{ Rock D } \\
\hline & \multicolumn{2}{|c|}{$\begin{array}{l}\text { Low } \\
\text { speed }\end{array}$} & \multicolumn{2}{|c|}{$\begin{array}{c}\text { high } \\
\text { speed }\end{array}$} & \multicolumn{2}{|c|}{$\begin{array}{c}\text { Low } \\
\text { speed }\end{array}$} & \multicolumn{2}{|c|}{$\begin{array}{c}\text { high } \\
\text { speed } \\
\end{array}$} & \multicolumn{2}{|c|}{$\begin{array}{c}\text { Low } \\
\text { speed }\end{array}$} & \multicolumn{2}{|c|}{$\begin{array}{c}\text { high } \\
\text { speed }\end{array}$} & \multicolumn{2}{|c|}{$\begin{array}{c}\text { Low } \\
\text { speed }\end{array}$} & \multicolumn{2}{|c|}{$\begin{array}{c}\text { high } \\
\text { speed }\end{array}$} \\
\hline & $\begin{array}{c}\mathrm{PR}, \\
\mathrm{mm} / \mathrm{sec}\end{array}$ & $\begin{array}{l}\text { S.E, } \\
\text { MPa }\end{array}$ & PR & S.E & PR & S.E & PR & S.E & PR & S.E & PR & S.E & PR & S.E & PR & S.E \\
\hline 12 & - & - & - & - & - & - & - & - & - & - & 3.15 & 0.7 & - & - & - & $\overline{-}$ \\
\hline 18 & - & - & - & - & - & - & - & - & 1.08 & 1.01 & 3.91 & 0.84 & 1.1 & 1.26 & 1.1 & 3.75 \\
\hline 24 & 1.08 & 1.44 & 3.89 & 1.2 & 1.05 & 1.25 & 2.28 & 1.72 & 1.09 & 1.34 & 3.41 & 1.29 & 1.11 & 1.67 & 3.54 & 1.56 \\
\hline 30 & 1.11 & 1.75 & 3.99 & 1.46 & 1.19 & 1.44 & 3.4 & 1.44 & 1.21 & 1.52 & 4.14 & 1.33 & 1.19 & 1.94 & 4.04 & 1.71 \\
\hline 36 & 1.13 & 2.07 & 4.5 & 1.55 & 1.29 & 1.52 & 3.8 & 1.55 & 1.51 & 1.46 & 3.27 & 2.02 & 1.39 & 1.99 & 4.32 & 1.92 \\
\hline 45 & 2.18 & 1.34 & 2.18 & 4.02 & 2.05 & 1.2 & 4.48 & 1.64 & 2.91 & 0.94 & 3.84 & 2.15 & 2.58 & 1.34 & 6.62 & 1.56 \\
\hline 60 & 1.07 & 3.63 & 3.5 & 3.32 & 1.5 & 2.18 & 3.63 & 2.7 & 3 & 1.22 & 5.65 & 1.94 & 3.58 & 1.29 & 7.46 & 1.85 \\
\hline 75 & 1.36 & 3.58 & 5.55 & 2.62 & 2.115 & 2.32 & 5.3 & 2.32 & 1.9 & 3.13 & 6 & 2.29 & 2.99 & 1.92 & 10.8 & 1.59 \\
\hline 90 & 1.86 & 3.13 & - & 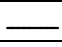 & 2.21 & 2.75 & 5.36 & 2.75 & 2.74 & 2.46 & 6.17 & 2.67 & 3.4 & 2.03 & 12 & 1.73 \\
\hline 105 & 2.76 & 2.46 & - & - & - & - & - & - & 5.19 & 4.51 & - & - & 3.34 & 2.41 & - & 2.3 \\
\hline 120 & 1.72 & 4.51 & - & - & - & - & - & - & 6.9 & - & - & - & 3.67 & 2.51 & - & \\
\hline
\end{tabular}


Figures $(1,2,3,4)$ illustrate the relation between WOB and penetration rate at two rotary speeds $400 \mathrm{rpm}$ and $1200 \mathrm{rpm}$.

The trend line for the results is that an increase WOB produces an increase in PR up to a maximum point. However, from the experimental data in table (3) a further increase in WOB causes constant or little increase in PR. The effect of rotational speed on PR of the bit is clear in the figures and data in table (3), an increase in rotary speed produced an increase in the PR. Relation between WOB and PR with correlation coefficients are given in Figs. (1), (2), (3), and (4). PR in rock (A) at WOB $105 \mathrm{~kg}$ was about 2.5 times that at $24 \mathrm{~kg}$. There is also an increase in PR at rocks (B), (C) and (D) with increased WOB. PR in rocks (B), (C) and (D) at WOB 90,120 and $120 \mathrm{~kg}$ was about 2, 6 and 3 times that at 24, and $18 \mathrm{~kg}$ respectively in the low speed. In high speed $\mathrm{PR}$ in rock (A) at WOB $75 \mathrm{~kg}$ was about 1.4 times that at $24 \mathrm{~kg}$. At WOB $90 \mathrm{~kg}$ in rocks (B), (C) and (D) PR increased abut 2, 2 and 10 times that at WOB 24, 12 and 18 $\mathrm{kg}$ respectively.

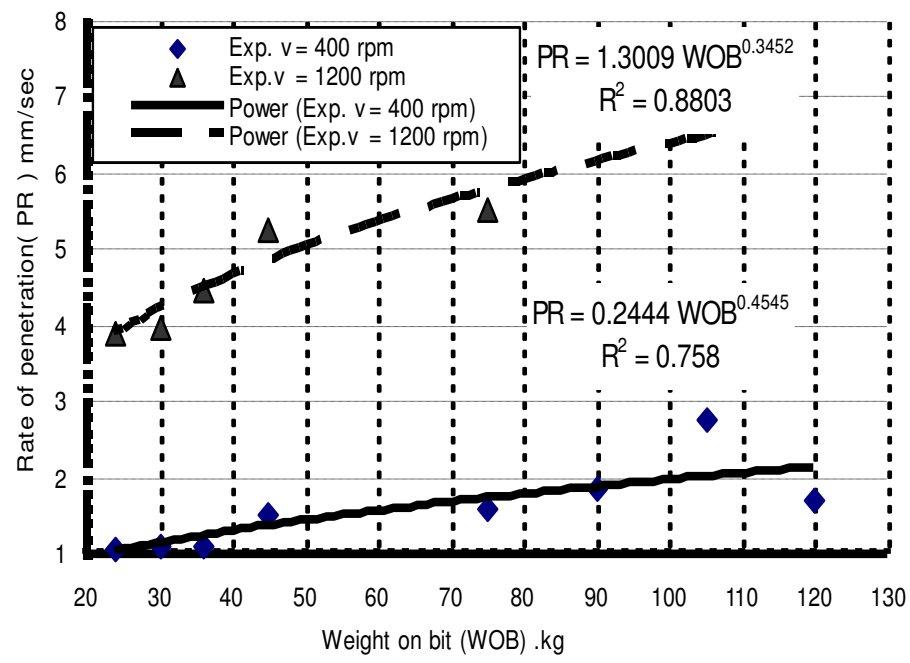

fig ( 1 ) Relation between WOB and PR for rock A in the high and low speed

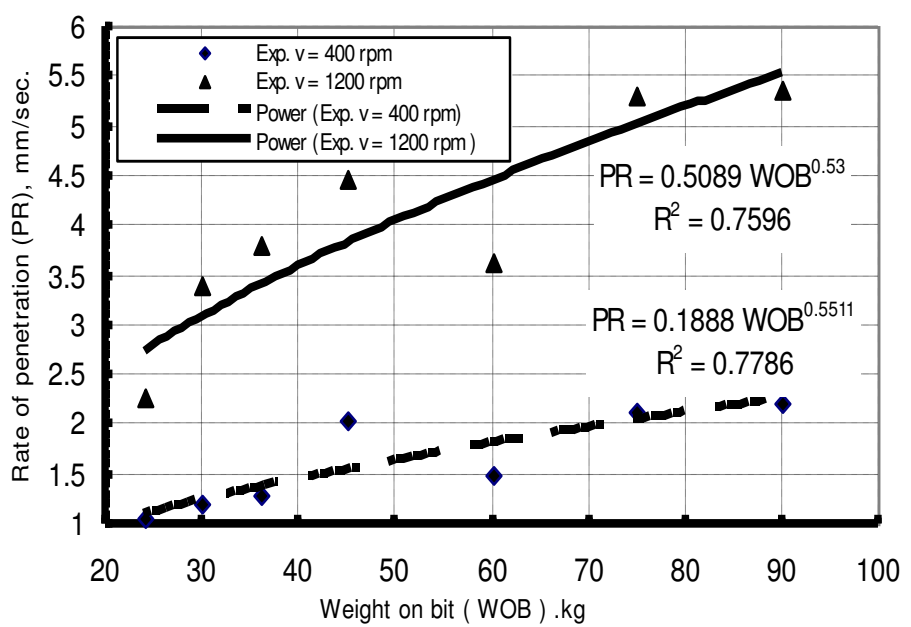

fig ( 2 ) Relation between WOB and PR for rock B in the high and low speed 


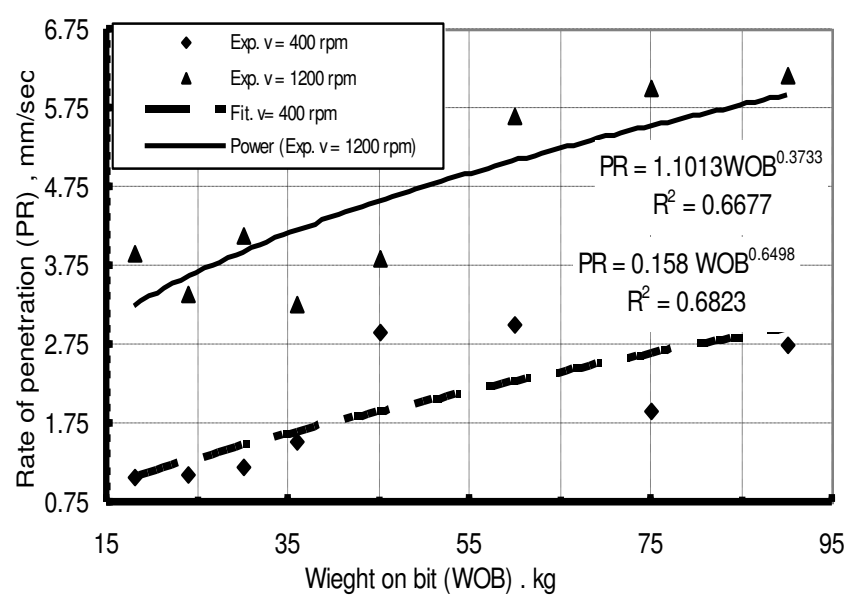

Fig.(3) Relation between WOB and ROP for rock $\mathrm{C}$ at high and low speed

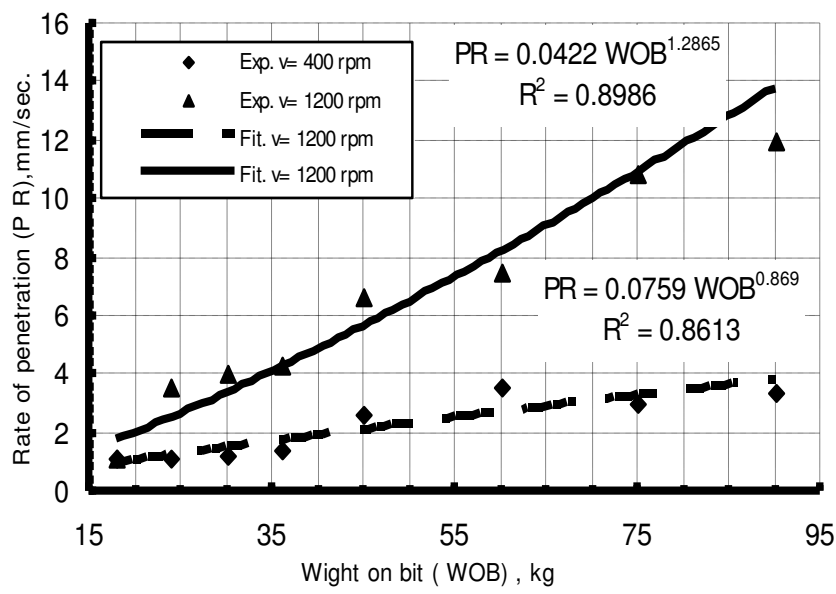

Fig.(4) Relation between WOB and ROP for rock D at high and low speed

\section{2- Relations between WOB and Torque:}

Torque is a force acts on a body to change its rate of rotation. It is the rotational equivalent of force in a linear motion system. Rotary torque is an indicator of what is happening at the drill bit and can be determined from the following equation [10].

$$
\mathrm{T}=\frac{2}{3} \mu \mathrm{F}_{\mathrm{v}} \frac{r_{o}^{3}-r_{i}^{3}}{r_{o}^{2}-r_{i}^{2}}
$$

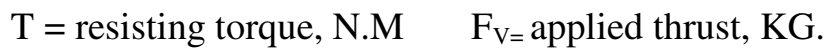

$\mathrm{r}_{\mathrm{o}}=$ outside radius, $\mathrm{m} \quad \mathrm{r}_{\mathrm{i}}$ inside radius, $\mathrm{m} \quad \mu=$ Coefficient of friction

Relationship between Torque and weight on bit is linear. The torque is found to be dependent on the weight on bit to the power of 1.1 according to field measurements. Table (4) gives the values of torque for the tested rocks which are calculated at different WOB. Relations between WOB and T are given in the figure (5) as an example; there is linear relation between WOB and T.

Torque value increases with increase in WOB in the four rocks. The following forms give the relations between WOB and T. 
For sandstone A $T=0.140 \mathrm{WOB}$

For sandstone C $T=0.132 W O B-0.001$
For sandstone B $T=0.118 \mathrm{WOB}-0.005$

For sandstone D $T=0.167$ WOB

Table (4) Values of torque for the tested rocks at different WOB

\begin{tabular}{|c|c|c|c|c|}
\hline \multirow{2}{*}{ WOB , KG } & ROCK A & ROCK B & ROCK C & ROCK D \\
\cline { 2 - 5 } & Torque, Nm & Torque, Nm & Torque, Nm & Torque, Nm \\
\hline 18 & - & - & 2.39 & 3.01 \\
\hline 24 & 3.38 & 2.85 & 3.19 & 4.01 \\
\hline 30 & 4.23 & 3.56 & 3.98 & 5.01 \\
\hline 36 & 5.07 & 4.27 & 4.78 & 6.01 \\
\hline 45 & 6.34 & 5.34 & 5.98 & 7.52 \\
\hline 60 & 8.45 & 7.12 & 7.97 & 10.02 \\
\hline 75 & 10.57 & 8.91 & 9.96 & 12.53 \\
\hline 90 & 12.68 & 10.69 & 11.95 & 15.03 \\
\hline 105 & 14.79 & - & 13.95 & 17.54 \\
\hline 120 & 16.9 & - & 15.94 & 20.05 \\
\hline
\end{tabular}

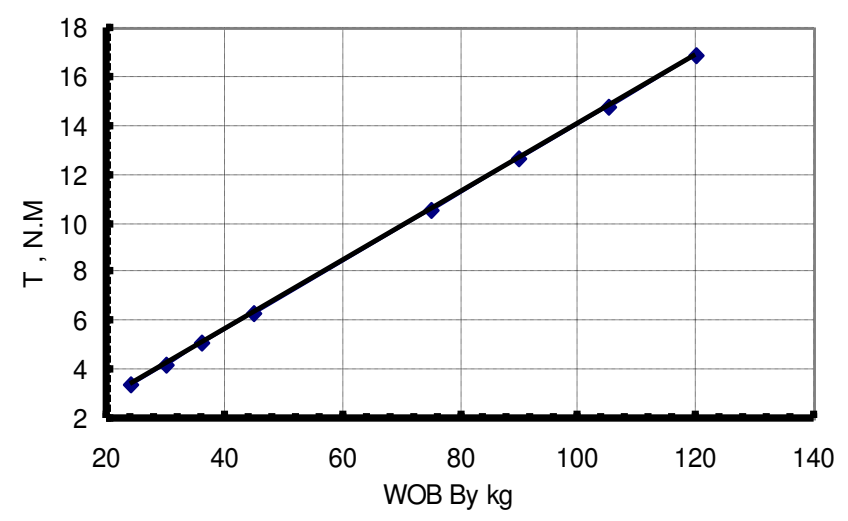

fig. (5) Relation betw een WOB and T in rock $A$

\section{3- Relations between WOB and SE at low and high speeds:}

Specific energy is directly related to the cost used to drill the hole, so the specific energy is the clear indication on the drilling performance in the rocks drilled in this study. Specific Energy (SE) can be defined as of the energy necessary to drill a determined volume of rock $\left(\mathrm{GJ} / \mathrm{m}^{3}\right)$. [5]

$$
\mathrm{SE}=2 \pi * \mathrm{NT} / \mathrm{A} * \mathrm{PR}
$$

Where,

$\mathrm{SE}=$ specific energy; $\mathrm{MPa}$.

$\mathrm{T}=$ resistance torque, $\mathrm{Nm}$.

$\mathrm{N}=$ rotary speed, $\mathrm{rpm}$.

$P R=$ penetration rate. $\mathrm{m} / \mathrm{hr}$.

$\mathrm{A}=$ area of the bit, $\mathrm{mm}^{2}$. 
Specific energy values calculated from the above equation for all tests in high and low speeds, and values are illustrated in table (3).

The relations between WOB and SE, with correlation coefficients and are given in the figs. (6), (7), (8) and (9). In these figures increase in WOB produced an increase in SE for all rocks in low and high speed. The best values of SE which gave reasonable values of PR were 1.34, 1.20, 0.94 and $1.34 \mathrm{MPa}$ at WOB $45 \mathrm{~kg}$ in rock (A), (B), (C) and (D) at $400 \mathrm{rpm}$ respectively.

The minimum values of SE which give the reasonable values of $P R$ were 1.20, $1.44,0.70$ and $1.56 \mathrm{MPa}$ at WOB $24,30,12$ and $45 \mathrm{~kg}$ in rock (A), (B), (C) and (D) at $1200 \mathrm{rpm}$ respectively .

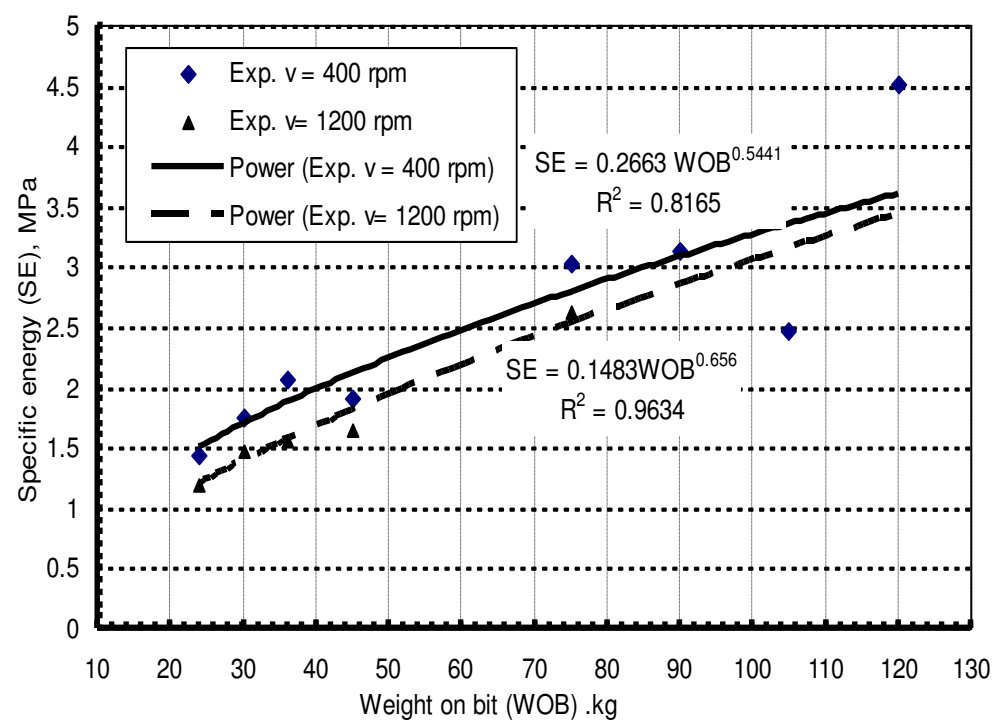

fig. (6) Relation between WOB and SE for S.S A at high and low speed

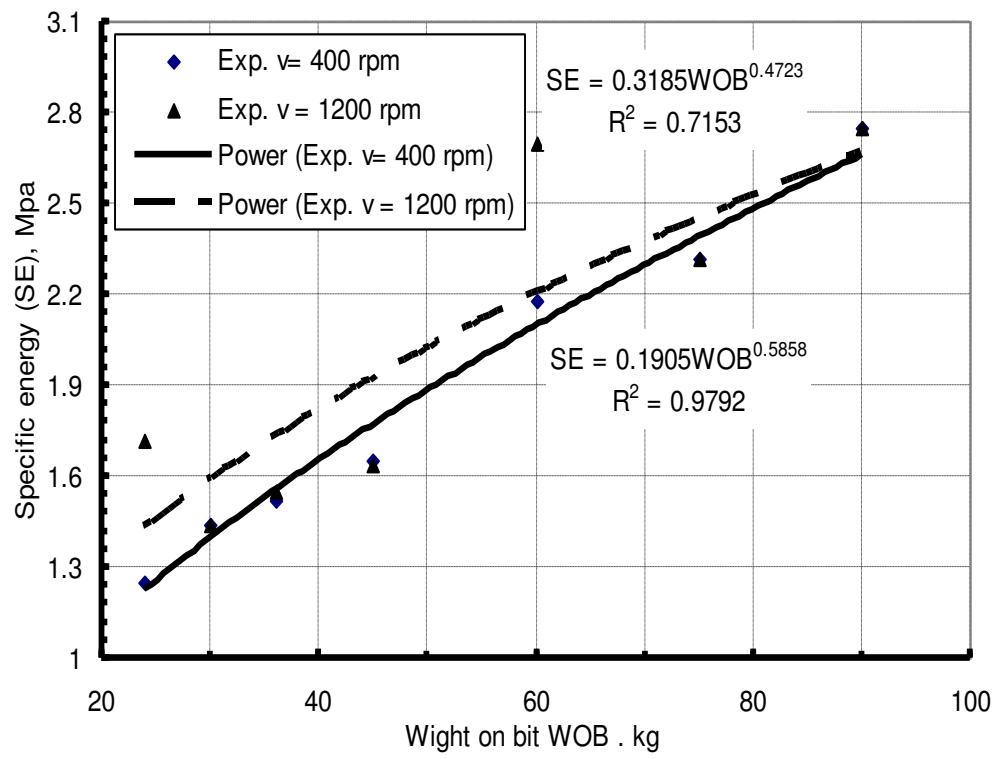

fig (7) Relation between WOB and SE for S.S B at low and high speed 


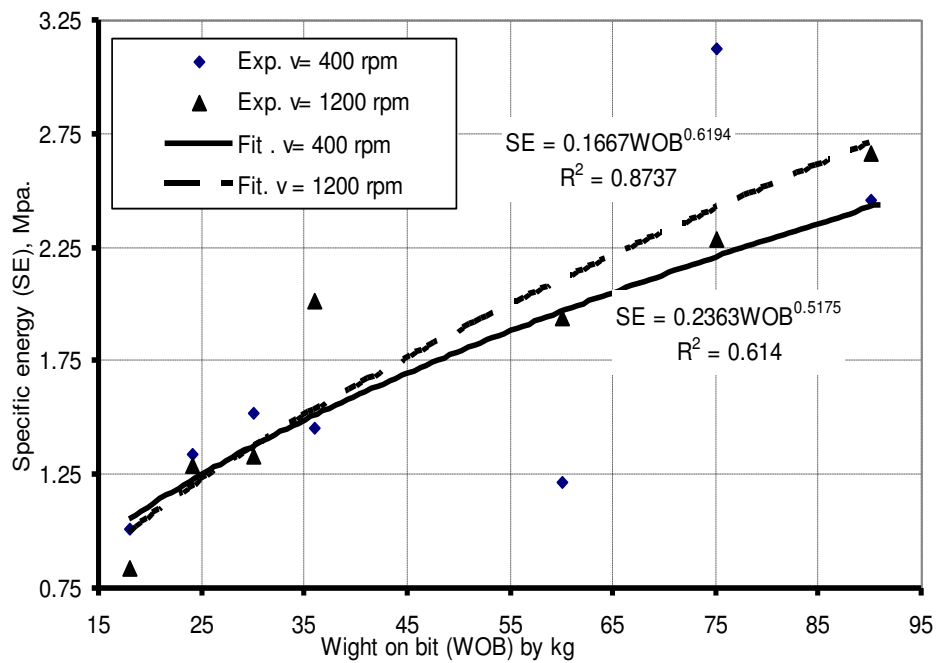

Fig.(8) Relation between WOB and SE for S.S $\mathrm{C}$ at high and low speed

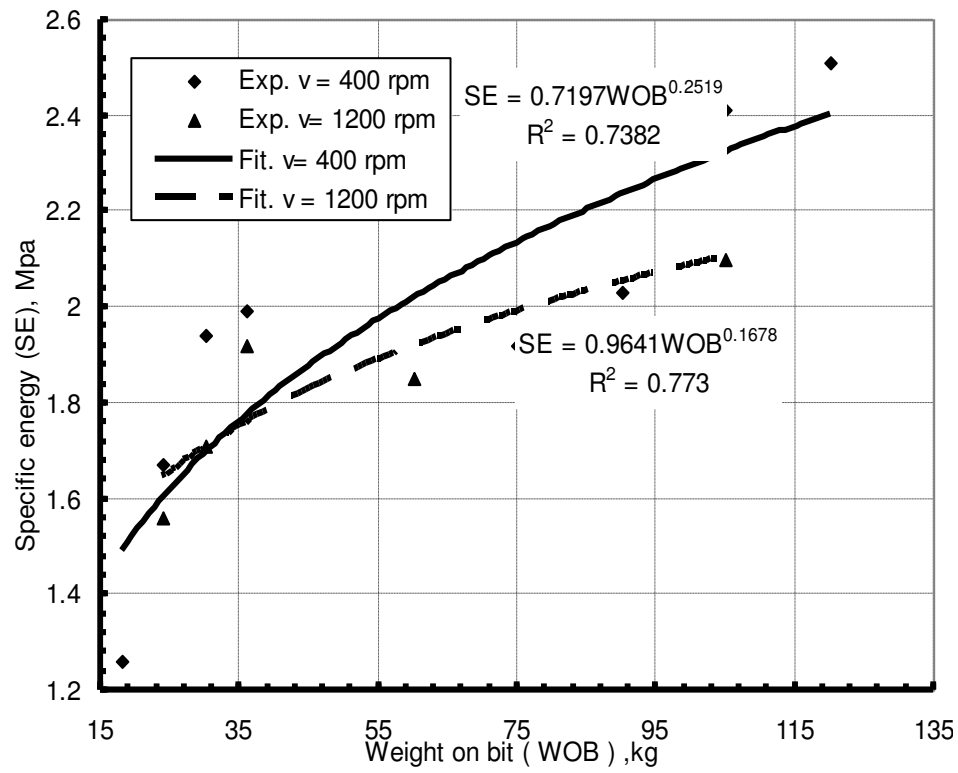

Fig.(9) Relation between WOB and SE for S.S D at high and low speed

\section{4- Relations between PR and SE at low and high speeds:}

Table (3) gives the different values of the SE and PR in the all rocks.

Figures (10), (11) give relations between PR and SE in sandstone (A) at low and high speed respectively. The SE increases with the increase in the PR to 3.63MPa, and with the increase of PR, SE decreases to 2.46 at low speed (400 rpm). The same trend happened at high speed (1200 rpm) as shown in Figs. (10), (11). 


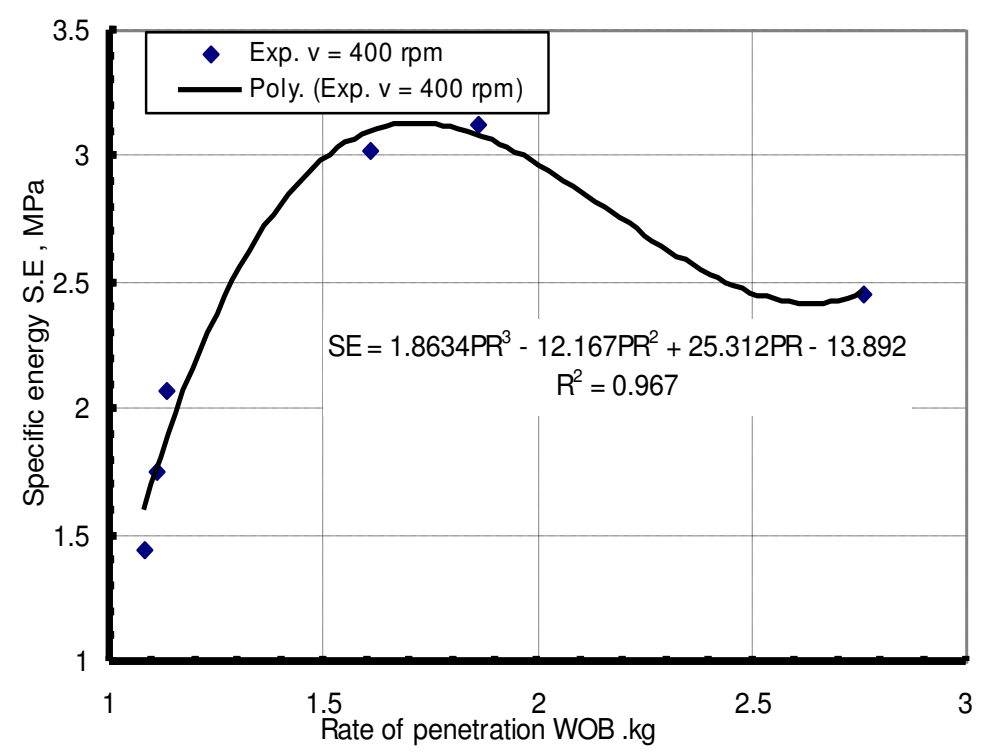

fig. (10) Relation betw een PR and S.Efor rock A at low speed

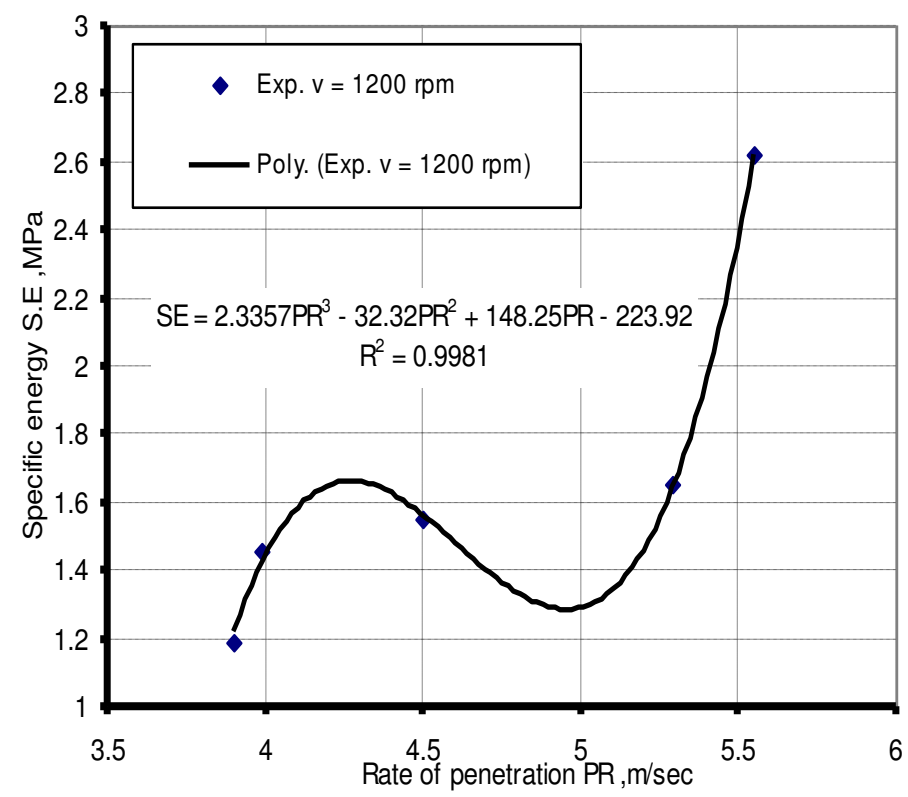

fig. (11) ) Relation betw een PR and S.Efor rock A at high speed

Figures (12), (13) illustrate the relations between PR and SE in the sandstone (B) at low and high speeds respectively. The SE decreases with the increase in PR at $\mathrm{PR}=1.5 \mathrm{~mm} / \mathrm{sec}$, $\mathrm{SE}$ was at the min. value $\mathrm{SE}=1.2 \mathrm{MPa}$ and the $\mathrm{SE}$ increases with the increase in PR, and this may be due to the wear in the bit. The same trend happened at high speed (1200 rpm) as shown in Figs. (12), (13). 


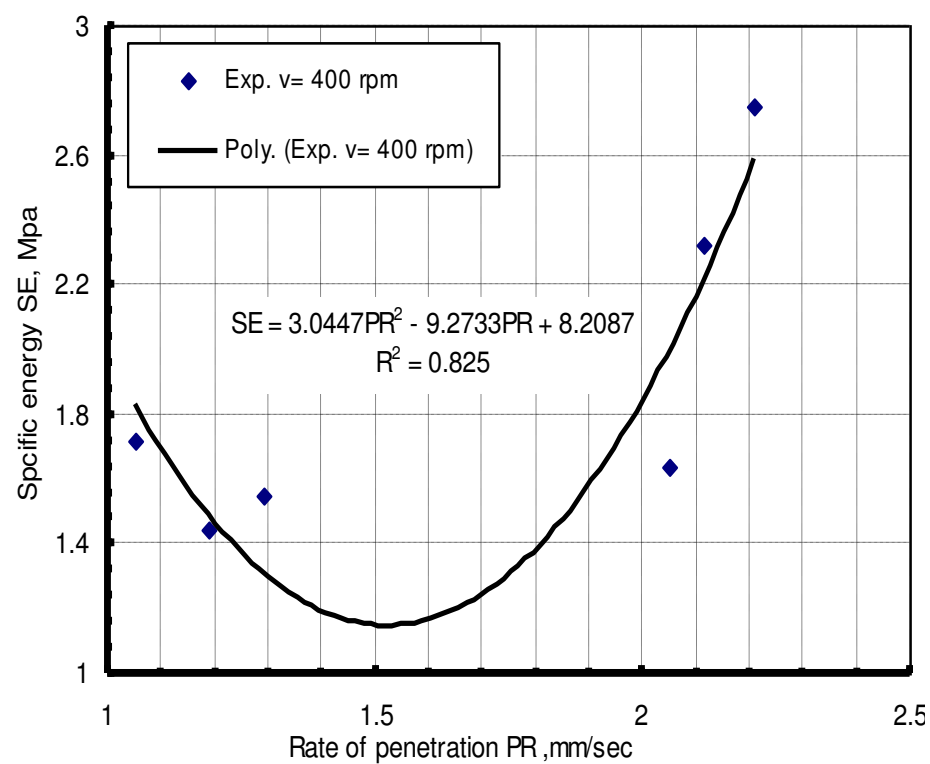

fig (12)Relation betw een PR and S.E for rock B at low speed

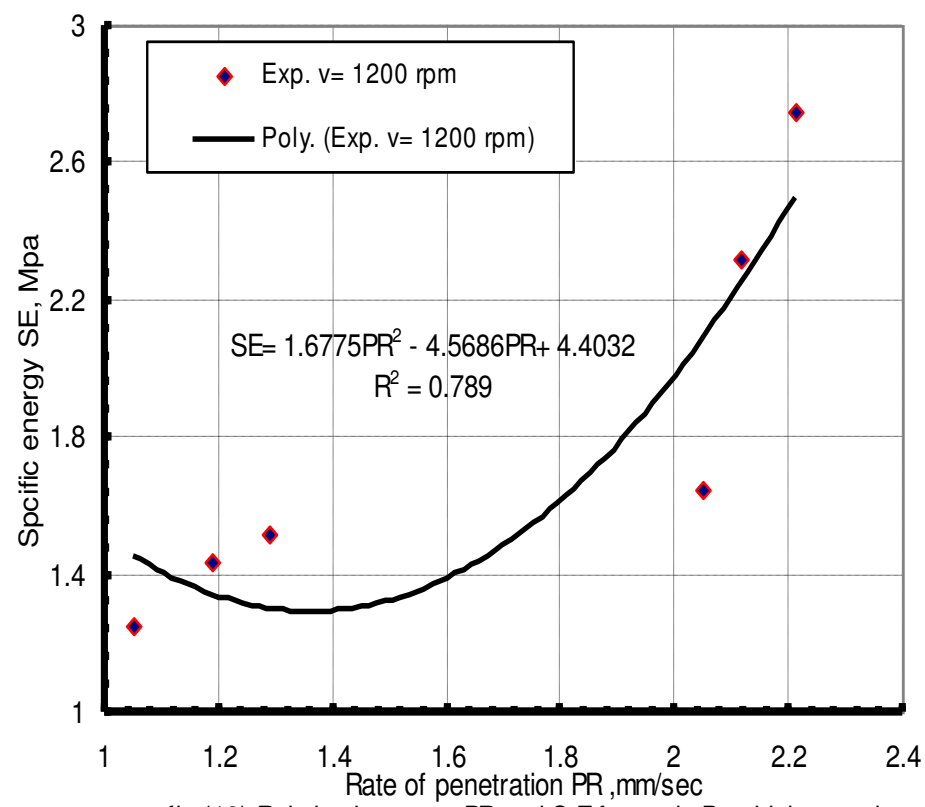

fig (13) Relation betw een PR and S.Efor rock B at high speed

Figures (14), (15) illustrate relations between PR and SE in the sandstone (C) at low and high speed respectively. At low speed, the SE decreases with an increase in $\mathrm{PR}$, at $\mathrm{PR}=2.5 \mathrm{~mm} / \mathrm{sec}$, $\mathrm{SE}$ was at the min. value $\mathrm{SE}=0.95 \mathrm{MPa}$ and the $\mathrm{SE}$ increases with the increase in PR which may be due to the wear in the bit. In high speed SE decreases with an increase in $\mathrm{PR}$, at $\mathrm{PR}=4.75 \mathrm{~mm} / \mathrm{sec}$, $\mathrm{SE}$ was at the min. value $\mathrm{SE}=$ 1.5 MPa and the SE increases with the increase in PR. 


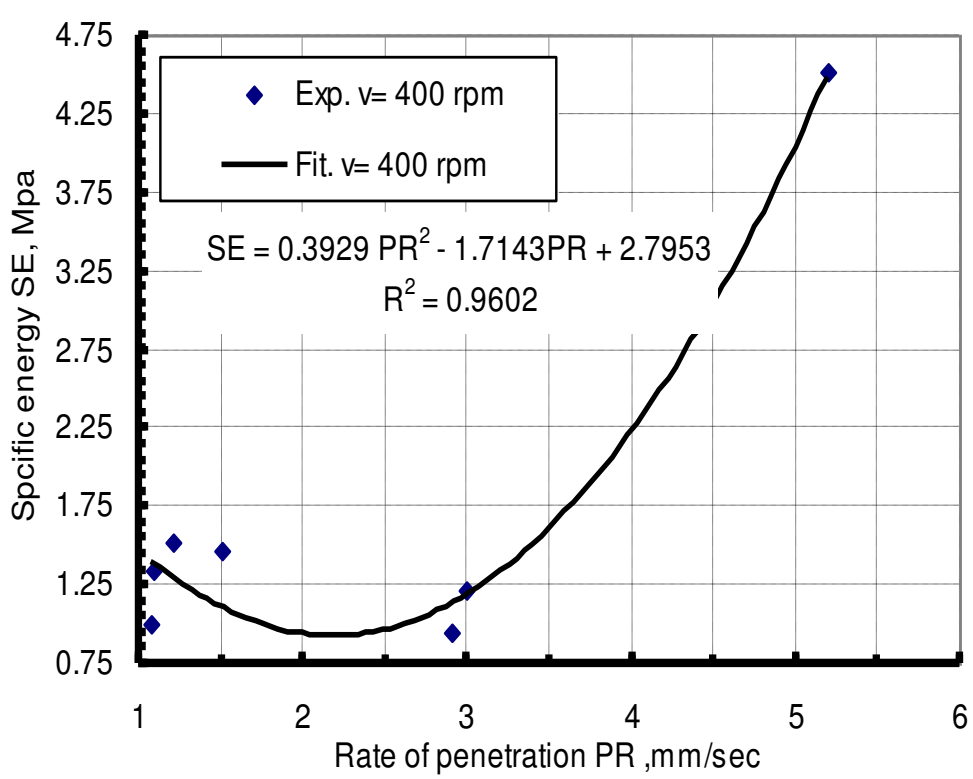

Fig.(14) ) Relation betw een PR and S.E for rock C at low speed

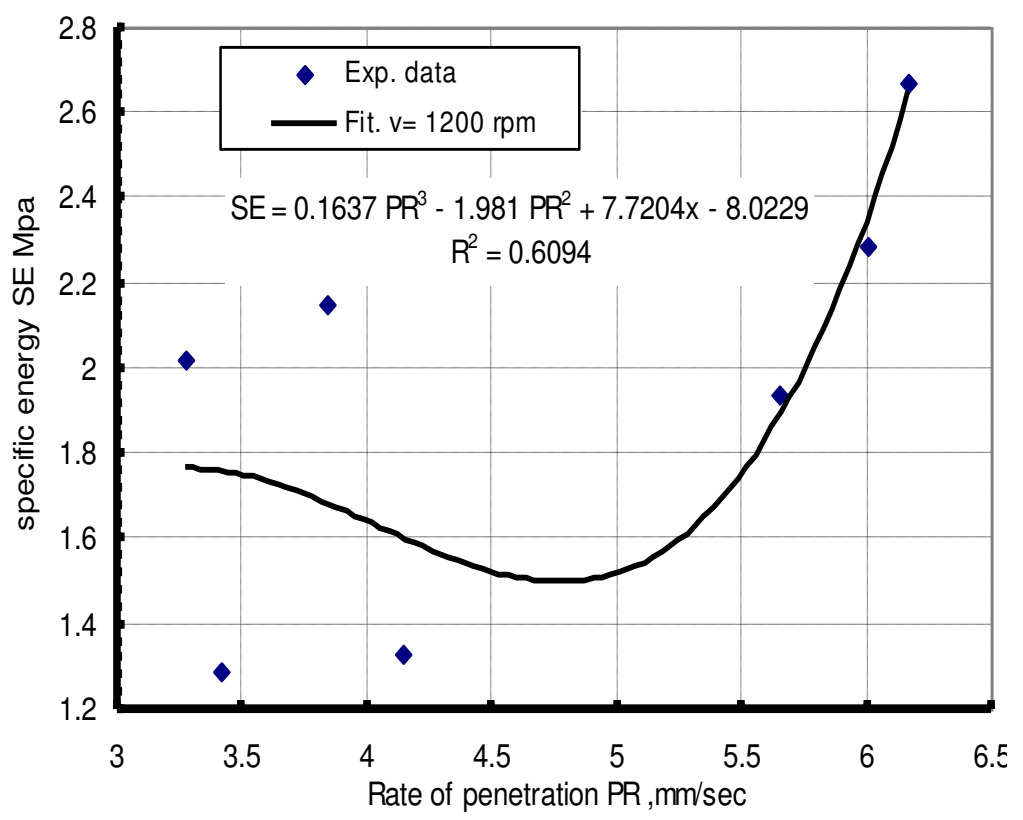

Fig.(15) Relation betw een PR and S.Efor rock $C$ at high speed

Figures (16), (17) illustrate the relations between PR and SE in the sandstone $\mathrm{D}$ at low and high speed respectively. SE increases with an increase in PR at the two speeds $(400,1200 \mathrm{rpm})$, this is because the used bit appears to be at the end of its life. 


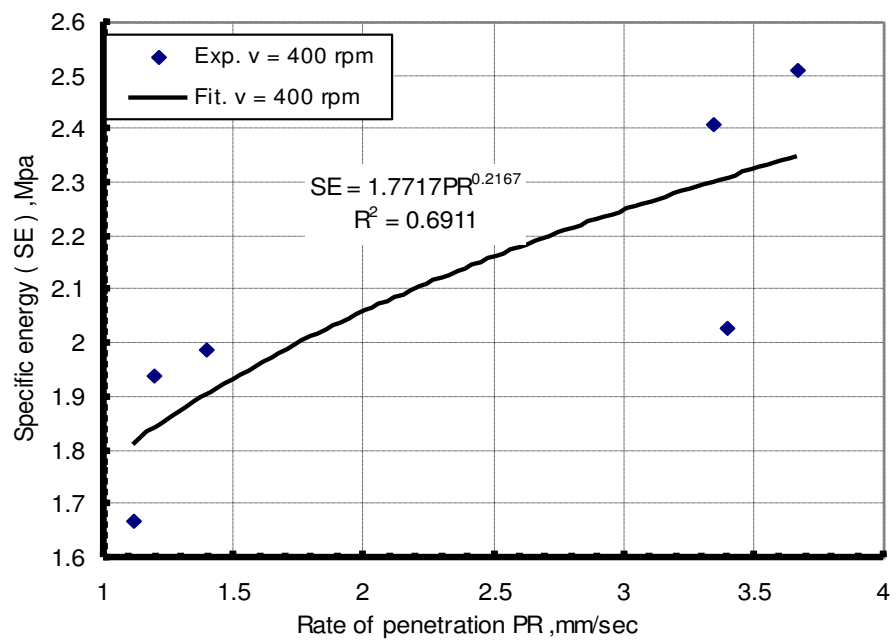

Fig.(16) ) Relation betw een PR and S.E for rock D at low speed

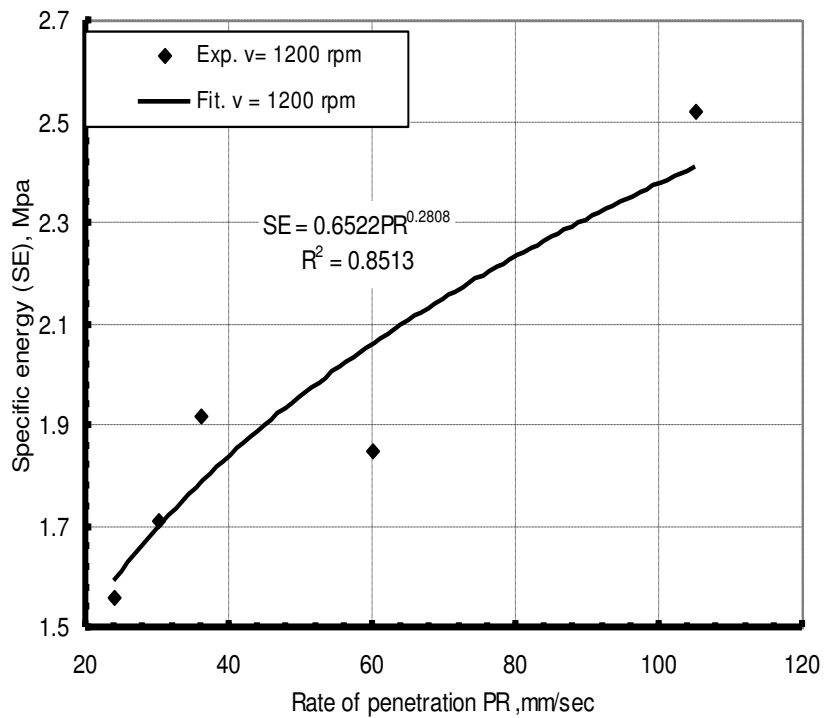

Fig.(17) Relation betw een PR and S.Efor rock D at high speed

\section{CONCLUSION}

- Four sandstone rocks were drilled by diamond core bit using a fixed laboratory drilling machine with two speeds at low speed $400 \mathrm{rpm}$ and high speed $1200 \mathrm{rpm}$, the range of the weight on bit applied started from 12 to $120 \mathrm{~kg}$.

- Relations between WOB and both PR, T, and SE were given, relation between PR and $\mathrm{SE}$ were also given. From experimental data drilling performance is dependant on operating parameters especially rotary speed and WOB. Mathematical equations between parameters are given from trend line on the curves.

- In low speed the increase of WOB causes an increase in PR. In rock (A) at maximum WOB $105 \mathrm{PR}$ was about 2.5 times that at minimum WOB $24 \mathrm{~kg}$. PR 
increase in rocks (B), (C) and (D) with increase WOB, at WOB 90, 120 and $120 \mathrm{~kg}$ the increase in PR was about 2, 6 and 3 times that at 24,18 and $18 \mathrm{~kg}$ respectively.

- The high speed increase in WOB produces an increase in PR, penetration rate in rock (A) at maximum WOB $75 \mathrm{~kg}$ was about 1.4 times that at $24 \mathrm{~kg}$. At WOB 90 $\mathrm{kg}$ in rocks (B), (C) and (D) PR increased about 2, 2 and 10 times that at WOB at 24,12 and $18 \mathrm{~kg}$ respectively.

- Penetration rate at high speed is more than that at low speed in a specific load. At WOB $90 \mathrm{~kg}$ as an example PR at high speed were about 3.1, 2.4, 1.9 and 3.5 times the $\mathrm{PR}$ at low speed in rocks (A), (B), (C) and (D) respectively.

- Increase in WOB produced an increase in SE for all rocks in low and high speed. The best values of SE which give reasonable values of PR were 1.34, 1.20, 0.94 and $1.34 \mathrm{MPa}$ at $\mathrm{WOB} 45 \mathrm{~kg}$ in rocks (A), (B), (C) and (D) at $400 \mathrm{rpm}$ respectively.

- The minimum values of SE which give the reasonable values of PR were 1.20, $1.44,0.70$ and $1.56 \mathrm{MPa}$ at WOB $24,30,12$ and $45 \mathrm{~kg}$ in rocks (A), (B), (C) and (D) at $1200 \mathrm{rpm}$ respectively .

- The quartz content as well as other intercalations in sandstone cause high wear in the bit used in drilling and cause also the differences in the relations between PR and SE which are clear from the curves and experimental data.

\section{REFRANCES}

[1] http://material.eng.usm.my/stafhome/termizi/EBS418E\%20Petroleum\%20E ng/4_Rotary\%20Drilling.doc

[2] Gamal Y. Boghdady "mechanical and geological influences on drilling limestone rock at low rotary speed" Journal of Engineering Sciences, Assiut University, Vol. 38 , No. 1,pp.259-270, January 2010.

[3] Bilim, N. "Determination of drillability of some natural stones and their association with rockproperties" ISSN 1992-2248-Academic Journals, 2011)

[4] Mohamed A.Sayed and Gamal Y. Boghdady "Optimization of diamond core bit performance utilizing high rotary speed in drilling limestone rocks" Journal of Engineering Sciences, Assiut University , Vol. 38 , No.6,pp.1531-1543, November 2010.

[5] Celada, B. Galera, J. M. Muñoz, C. Tardáguila,I. "The use of the specific drilling energy for rock mass characterization and TBM driving during tunnel construction"

http://www.geocontrol.es/lista/listado/vdocumento.asp?f=use \% 200 \% $\%$ specific\%20drilling_celada.pdf

[6] M.M. El-Beblawi, Mohamed A. Sayed, M.T. Mohmed , W.R . El-Rawy "Some drilling parameters as a tool to predict different categories of rocks" Journal of Engineering Sciences , Assiut University , Vol. 35 , No.4, pp.9951008 , July 2007.

[7] Thuro, K. "Drillability prediction - geological influences in hard rock drill and blast tunnelling". Geol Rundech 86 : 426 - 428 , 1997

[8] Mohamed A. Sayed and Abdel Nasser M. Abdel Rahman " Using diamond core drilling parameters for identifying the rock type to be drilled" Journal of Engineering Sciences, Assiut University, Vol. 30 , No.4 ,pp.1011-1025, 
October 2002.

[9] RAO, K. U. M. BHATNAGAR, A. and MISRA, B. "Laboratory investigations on rotary diamond drilling" Geotechnical and Geological Engineering 20: 1-16, 2002.

[10] Sayed, M. A. "Relation between operating parameters and bit performance in diamond core drilling" " MPM " 7 - Assiut, Egypt, Feb.10-12, 2001

\section{تأثير عوامل التثنغيل وخواص التكوينات الصخرية علي معدل الاختراق في بعض صخور الحجر الرملي باستخدام بنطة حفر مطعمة بالماس}

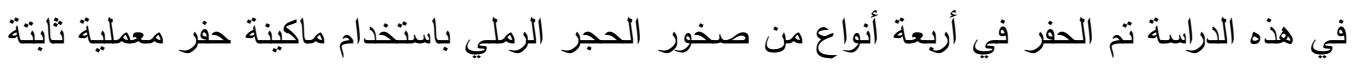

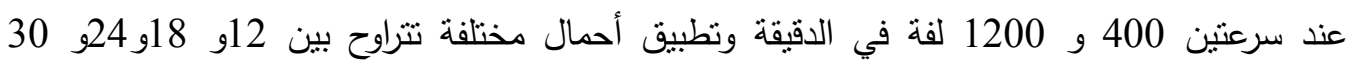

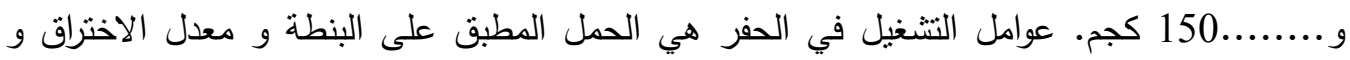

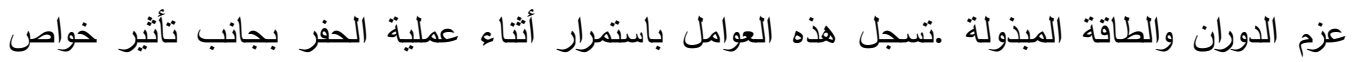
التكوينات الصخرية على معدل الاختراق ـ نم استتناج العلاقة بين الحمل المطبق على البنطة وكل من معدل الاختراق وعزم الدوران وكمية الطاقة المبذولة. وكذلك العلاقة بين معدل الاختراق والطاقة المبذولة

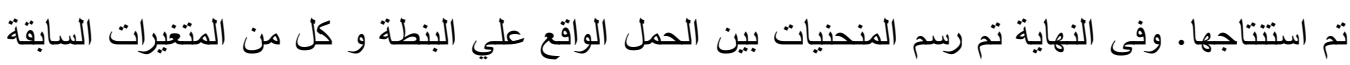

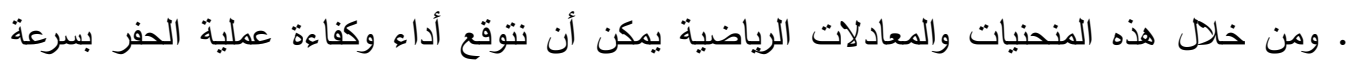

